\title{
O banco mundial nos anos $1960^{*}$
}

João Márcio Mendes Pereira**

Resumo: O artigo discute a trajetória do Banco Mundial nos anos 1960, relacionando-a com a economia internacional e a política externa americana. Identifica o perfil organizacional construído nos anos 1950, profundamente marcado pela dependência financeira de Wall Street, e analisa um conjunto de pressões políticas e econômicas internacionais que acabaram por impor a realização de mudanças na estrutura organizacional e na política de crédito da entidade. Ainda, caracteriza as grandes linhas do crescimento acelerado do Banco durante os anos 1960 em termos de volume de empréstimos, número de Estados clientes, orçamento administrativo e tamanho do quadro de funcionários. Discute também a diversificação relativa do perfil dos projetos financiados.

Palavras-chave: Banco Mundial. Estados Unidos. Guerra fria. Revolução verde. Ajuda externa americana.

Não é difícil perceber por que os comunistas vêem nas áreas subdesenvolvidas uma arena de oportunidades. O processo de modernização provoca modificações radicais não apenas na economia dessas naçoes, mas também em sua estrutura social e em sua vida politica. Vivemos, literalmente, numa época revolucionária. Devemos esperar que na próxima década as agitações se repitam nessas áreas. Walt W. Rostow (1964, p. 36).

\footnotetext{
* Pesquisa financiada pelo CNPq e pela FAPERJ.

** Doutor em História pela UFF, professor adjunto de História da América Contemporânea da UFRRJ, professor do quadro permanente do Programa de Pós-Graduação em História da UFRRJ e professor colaborador do Programa de Pós-Graduação em Desenvolvimento Territorial na América Latina e Caribe da UNESP. E-mail: joao_marcio1917@yahoo.com.br.
} 
Dada a relação existente entre a estagnação econômica e a incidência da violência, os anos que aguardam as nações situadas na parte meridional do globo afiguram-se lúgubres. Isso seria verdadeiro mesmo que não existisse qualquer ameaça de subversão de ordem comunista, como, evidentemente, existe. Tanto Moscou como Pequim [...] consideram o processo de modernização um ambiente ideal para a expansão do comunismo [...]. Permanece o fato incontestável de nossa segurança estar diretamente ligada à segurança desse novo mundo em desenvolvimento [...]. Sem desenvolvimento interno, pelo menos em grau minimo, ordem e estabilidade são impossiveis. Robert McNamara (1968, p. 171, p. 173).

\section{Introdução}

Próximo de completar setenta anos de existência, o Banco Mundial há décadas ocupa lugar central na definição e veiculação de ideias, práticas e políticas internacionais de desenvolvimento de ampla magnitude. Contudo, nem sempre foi assim. Para entender parte da sua trajetória ascendente, este artigo debruça-se sobre a atuação da entidade durante os anos de 1960, relacionando-a à dinâmica da economia internacional e da política externa americana. Busca identificar o perfil organizacional construído nos anos 1950, profundamente marcado pela dependência em relação ao mercado financeiro americano, simbolizado por Wall Street, e por um conjunto de pressões políticas e econômicas que acabaram por impor a realização de mudanças na estrutura organizacional e na política de crédito da entidade. $O$ trabalho, ainda, identifica as linhas do crescimento acelerado do Banco entre 1960 e 1968 no que diz respeito a volume de empréstimos, número de Estados clientes, orçamento administrativo e tamanho da burocracia. Discute também a diversificação relativa do perfil dos projetos financiados, destacando as inovações promovidas no período. Ao final, apresenta as principais conclusões, argumentando que o período em apreço constituiu uma fase de transição fundamental na história da entidade. 


\section{Guerra Fria e primeiros anos de operação do Banco Mundial (1946-60)}

Já em 1941, antes do ataque japonês à base naval de Pearl Harbor, o governo americano iniciou a elaboração de propostas para o desenho da nova arquitetura econômica internacional que se institucionalizaria em tempos de paz. Impulsionado pelo aumento astronômico do PIB nacional durante a guerra, o objetivo de Washington era criar as condições que assegurassem o livre comércio para os produtos americanos, a abertura dos mercados estrangeiros ao capital estadunidense e o acesso irrestrito a matérias-primas necessárias ao dinamismo da maior potência econômica e militar do planeta. Movido por esse ideário, o governo Roosevelt patrocinou a realização da Conferência Monetária e Financeira das Nações Unidas, em julho de 1944, na cidade de Bretton Woods (EUA). O resultado do encontro materializou a hegemonia americana na reorganização política e econômica internacional do pós-guerra (GARDNER, 1994; VAN DORMAEL, 1978; BLOCK, 1989; HELLEINER, 1996; PAULY, 1997). Produto de uma mudança drástica na estrutura de poder internacional, institucionalizou uma nova ordem monetária baseada no dólar, razão pela qual a política econômica dos Estados Unidos centralizaria a criação de liquidez e forjaria as condições da expansão e da internacionalização do capital americano. Ao mesmo tempo, criaram-se organizações financeiras multilaterais de novo tipo, como o Fundo Monetário Internacional (FMI) e o Banco Internacional para a Reconstrução e o Desenvolvimento (BIRD), cuja ossatura institucional expressava e reproduzia a desigualdade de poder configurada no sistema internacional (EICHENGREEN, 2000; TABB, 2004; WOODS, 2006).

Pouco depois, no início de 1947, teve início a guerra fria. Com base na Doutrina Truman, o governo americano passou a oferecer assistência política, econômica e militar aos "povos livres", i.e., a qualquer governo (democrático ou ditatorial) supostamente sob ameaça comunista interna ou externa (BANDEIRA, 2006, p. 145147; FONTANA, 2011, p. 42-50). Para competir com a URSS e 
administrar a economia mundial sob sua égide, os EUA precisavam de parceiros subalternos fortes. Por isso, os EUA concederam ajuda econômica farta a aliados estratégicos, como a Europa Ocidental, o Japão, o Canadá e a Austrália.

O instrumento principal dessa política foi a ajuda bilateral. Entre 1948 e 1952, por meio do Plano Marshall - a principal ação da época - os EUA concederam a dezesseis países cerca de US $\$ 13,5$ bilhões, dos quais mais de $90 \%$ em condições altamente facilitadas, o que representou, na época, pouco mais de $4 \%$ do PIB americano (SOGGE, 2002, p. 21-22). Na esteira dessa iniciativa, os EUA criaram uma ampla infraestrutura institucional de assistência financeira, militar, técnica e científica, deslanchando diversas outras ações bilaterais para o conjunto dos países do "mundo livre" (LANCASTER, 2007; KRIGE, 2006; ROBIN, 2001). Essa atuação foi fundamental para, em nome da liberdade e da democracia, disseminar instituições americanas no exterior, administrar politicamente o mundo não comunista e conter o comunismo dentro das suas próprias fronteiras.

Ao lado das iniciativas bilaterais, o governo americano buscou instrumentalizar as instituições financeiras multilaterais criadas em Bretton Woods para fins coerentes com a sua política externa. O BIRD - logo chamado de Banco Mundial, a partir de meados dos anos 1950 — foi uma delas. ${ }^{1}$ Forjado como parte da infraestrutura de poder global dos Estados Unidos erguida no pós-guerra (GWIN, 1997; KOFAS, 2005; PEREIRA, 2010), o BIRD nasceu com recursos insuficientes para as metas que deveria cumprir: financiar a reconstrução dos países devastados pela guerra e, secundariamente, promover o desenvolvimento do mundo subdesenvolvido. Apequenado diante da magnitude financeira do Plano Marshall, a instituição acabou tendo papel menor na reconstrução. ${ }^{2}$ Mesmo assim, empréstimos para o "desenvolvimento" do então chamado Terceiro Mundo somente se tornariam o carro-chefe da sua atuação a partir do final dos anos 1950.

Tanto para fins de reconstrução como de desenvolvimento, o Banco concedia empréstimos de dois tipos: para programas e projetos. No primeiro caso, as operações eram de volume financeiro maior e tinham o objetivo, em geral, de financiar importações ou 
aliviar desequilíbrios no balanço de pagamentos, sendo autorizadas em circunstâncias especiais para clientes considerados mais solventes e politicamente estratégicos para os EUA, como os países europeus e o Japão. No segundo caso, os empréstimos eram menores e se destinavam ao financiamento de projetos produtivos específicos, autorizados para clientes considerados menos solventes - na maioria dos casos, países de renda média (KAPUR et al., 1997, p. 129; KOFAS, 2005, p. 21; KIRK, 2010, p. 7).

O financiamento de projetos "produtivos" simbolizava, antes de tudo, o veto preventivo dos bancos americanos à concorrência financeira que o BIRD pudesse lhes fazer (MASON; ASHER, 1973, p. 24; KOLKO, 1990, p. 257). Para atrair interessados na compra de títulos do Banco, a instituição adotou uma política creditícia conservadora, pautada pela rentabilidade comercial de suas operações. Os empréstimos do Banco tinham que ser lucrativos e a forma considerada mais adequada para assegurar isso era financiar projetos tangíveis. Segundo essa visão, investimentos em infraestrutura podiam demonstrar para onde ia e como era empregado o dinheiro, o que, por sua vez, era usado como elemento de propaganda junto a investidores privados, para que comprassem mais títulos do Banco. É verdade que, quando questões políticas estavam em jogo, tal obrigatoriedade não impedia que o BIRD camuflasse créditos para aliviar crises em balanços de pagamentos como se fossem empréstimos para projetos específicos (KAPUR et al., 1997, p. 123). Mas a regra, de todo modo, prescrevia empréstimos para projetos produtivos.

Desse modo, até 1962, a maior parte dos empréstimos do BIRD financiou projetos para a geração de energia elétrica por meio da construção de grandes represas e usinas termoelétricas; secundariamente, a construção de vias de transporte e telecomunicações; em menor escala, a compra de máquinas e implementos agrícolas e projetos de irrigação para produção de gêneros exportáveis; marginalmente, emprestou-se para a modernização de indústrias domésticas de transformação. Ao longo dos primeiros dezesseis anos de operação, o BIRD não autorizou nenhum empréstimo para a área "social" (saúde e educação), diferentemente do que fazia a ajuda bilateral americana (KAPUR et al., 1997, p. 119). Os projetos elegíveis ao financiamento tinham de ser lucrativos. Deveriam, também, efetuar 
os gastos predominantemente em dólar. Projetos para fins "sociais" não atendiam a tais exigências (GAVIN; RODRIK, 1995, p. 333).

Além disso, a confiança dos banqueiros americanos nos títulos do BIRD foi alimentada pelo fato de que os acordos de empréstimo da instituição com os Estados clientes estabeleciam que os recursos deviam ser gastos na compra de bens e serviços de empresas situadas nos países capitalistas mais ricos. De 1949 a 1962, nunca menos de $92 \%$ das quantias emprestadas foram gastas anualmente na compra de mercadorias de empresas situadas naqueles países, como mostra a tabela 1. Assim, o Banco cumpriu o papel de introduzir ou fortalecer a presença de empreiteiras, bem como de bancos americanos e europeus no centro das relações comerciais e de produção entre os EUA, a Europa, o mundo colonial e a periferia capitalista (GOLDMAN, 2005, p. 30).

\section{Tabela 1 - Distribuição geográfica dos gastos efetuados com os empréstimos do Banco Mundial - 1946-62 (Percentual)}

\begin{tabular}{c|c|c|c|c|c|c|c|c}
\hline País & Até $\mathbf{1 9 5 5} \mathbf{( a )}$ & $\mathbf{1 9 5 6}$ & $\mathbf{1 9 5 7}$ & $\mathbf{1 9 5 8}$ & $\mathbf{1 9 5 9}$ & $\mathbf{1 9 6 0}$ & $\mathbf{1 9 6 1}$ & $\mathbf{1 9 6 2}$ \\
\hline Alemanha & 4.1 & 14.1 & 18.6 & 17.2 & 16.3 & 16.9 & 13.5 & 10.9 \\
\hline Bélgica & 3.7 & 2.9 & 2.8 & 2.9 & 3.3 & 2.1 & 2.5 & 1.6 \\
\hline Canadá & 5.6 & 7 & 6 & 1.1 & 0 & 2.3 & 1.5 & 1.1 \\
\hline $\begin{array}{c}\text { Estados } \\
\text { Unidos }\end{array}$ & 63.4 & 50.5 & 44.3 & 38.8 & 29.7 & 29.8 & 29.6 & 33.2 \\
\hline França & 2.7 & 3.3 & 3.5 & 1.2 & 5.2 & 6.7 & 12 & 12.3 \\
\hline Itália & 0.9 & 1.7 & 3 & 5.8 & 6.3 & 7.7 & 6.6 & 8.3 \\
\hline Japão & 0 & 0.2 & 2.2 & 8.3 & 6.2 & 3.9 & 6.1 & 5 \\
\hline Países Baixos & 0 & 0 & 0 & 0 & 0 & 0 & 0 & 2.5 \\
\hline Suécia & 0.7 & 1.5 & 2.7 & 0.9 & 2.1 & 2.3 & 3.1 & 2.6 \\
\hline Suíça & 2.1 & 2.3 & 1.9 & 1.3 & 2.7 & 4.3 & 4.5 & 3.6 \\
\hline Reino Unido & 11.1 & 13.2 & 10.9 & 18.8 & 20.5 & 16.5 & 13.7 & 13.7 \\
\hline Subtotal & 94.2 & 96.7 & 95.9 & 96.3 & 94.4 & 92.5 & 93.1 & 94.7 \\
\hline $\begin{array}{c}\text { Demais } \\
\text { países }\end{array}$ & 5.8 & 3.3 & 4.1 & 3.7 & 5.6 & 7.5 & 6.9 & 5.3 \\
\hline Total & 100 & 100 & 100 & 100 & 100 & 100 & 100 & 100 \\
\hline
\end{tabular}

Fonte: Toussaint (2006, p. 39), com base nos relatórios anuais do Banco de 1946 a 1962.

(a) Média dos nove primeiros anos de atividade. 
Além disso, parte desses empréstimos foi destinada ao financiamento de projetos em áreas coloniais de interesse das suas respectivas metrópoles, contribuindo para provê-las de matérias-primas ou simplesmente abrir ou expandir frentes de negócios para empresas metropolitanas (KAPUR et al., 1997, p. 687). Desse modo, o Banco contribuiu, por exemplo, para que a Bélgica, o Reino Unido, a França e a Holanda prosseguissem com a sua dominação colonial e depois aplainassem o terreno para a dependência econômica pós-colonial. Nesses casos, os recursos emprestados foram gastos, quase que integralmente, na importação de bens e serviços de empresas metropolitanas, com o agravante de que as dívidas contraídas pelas potências foram depois transferidas aos novos Estados independentes (TOUSSAINT, 2006, p. 40-41).

Durante esse período, o BIRD passou a considerar seus projetos como vitrines para a disseminação de negócios lucrativos e orientações sobre o que fazer, como e para quem, em matéria de desenvolvimento. $\mathrm{Na}$ visão do Banco, os projetos cumpriam um "papel educacional" junto à burocracia estatal nos países clientes (KAPUR et al., 1997, p. 125-126). Isso ocorria por meio da assistência técnica fornecida pela entidade, normalmente ligada a acordos de empréstimo, e em geral resultava na montagem de agências específicas para administrar projetos, ou simplesmente pelo atrelamento da liberação de recursos ao "bom comportamento" dos clientes em matéria de política econômica — p. ex., a inexistência de atitudes hostis contra o capital estrangeiro.

Em 1962, após quinze anos em funcionamento, o BIRD havia emprestado mais de seis bilhões de dólares em mais de trezentas operações e auferia lucros anuais a uma taxa considerada "quase indecente" (MASON; ASHER, 1973, p. 407). Porém, o outro lado dessa performance foi, na prática, o fechamento da instituição aos países mais pobres, uma vez que eles não eram considerados solventes e, portanto, não eram elegíveis aos empréstimos do BIRD. Mesmo para países de renda média - maiores clientes do Banco depois da India - as condições de empréstimo eram consideradas onerosas.

Em outras palavras, nos seus primeiros anos em operação, o BIRD distinguiu-se tanto das agências americanas de ajuda econômica 
bilateral quanto de outras organizações multilaterais - como a Organização das Nações Unidas para Agricultura e Alimentação (FAO), a Organização das Nações Unidas para a Educação, a Ciência e a Cultura (UNESCO) e a Organização Mundial da Saúde (OMS) —, para as quais agricultura, educação e saúde eram setores estratégicos. Por adotar uma política creditícia conservadora, baseada na rentabilidade comercial e no foco em projetos voltados à construção de infraestrutura física, não havia qualquer subsídio nas suas operações financeiras nem o financiamento a setores considerados não lucrativos (KAPUR et al., 1997, p. 188-189). Isso não impediu que a instituição, sob orientação do Departamento de Estado ou do Departamento do Tesouro, concedesse ou negasse empréstimos para clientes segundo razões de ordem política, nem evitou que as condições impostas para a autorização de empréstimos variassem de acordo com critérios políticos (KOFAS, 2005, p. 7-28; KOFAS, 2002, 1999; 1995; GARCÉS, 2008, p. 106; GWIN, 1997). Contudo, a preferência de Washington por conduzir operações visivelmente políticas mais por canais bilaterais do que multilaterais criou uma margem de manobra para que o BIRD se consolidasse como um ator financeiro fortemente ligado ao mercado de capitais americano, simbolizado por Wall Street, e aparentasse certa distância da guerra fria.

\section{Pressões por mudança e criação da Associação Internacional de Desenvolvimento}

Essa posição singular passou a sofrer um conjunto de pressões internacionais durante a segunda metade dos anos 1950 que obrigou o Banco a realizar mudanças e adaptações na sua estrutura de funcionamento e no seu modo de atuação.

A primeira pressão originou-se da dinâmica da guerra fria. Desde o fim da II Guerra Mundial, a orientação da política externa americana sistematizada por George Kennan ${ }^{3}$ consistia em conter o comunismo dentro de suas próprias fronteiras, por meio da combinação de intervenção e alianças político-militares, ofensivas militares em larga escala, ajuda econômica (bilateral e multilateral) e diplomacia.

Anos 90, Porto Alegre, v. 21, n. 40, p. 493-531, dez. 2014 
O primeiro território em disputa foi a Europa. Porém, com o encaminhamento da reconstrução europeia e a eclosão da revolução comunista na China em 1949 e da Guerra da Coreia (1950-1953), o palco principal da contenção deslocou-se para a Ásia, abarcando os países situados ao longo das bordas da URSS e da China até as Filipinas. Outras regiões contavam pouco, tanto que, no final da década de cinquenta, apenas dois porcento da ajuda econômica norte-americana eram alocados na América Latina e menos ainda na África (KAPUR et al., 1997, p. 143). Esse quadro mudou na segunda metade da década de 1950, por três razões fundamentais.

Em primeiro lugar, devido ao processo de independência das colônias europeias. A partir de 1945, o número de novos Estados aumentou continuamente na África e na Ásia e, em muitos casos, as lutas de libertação nacional resultaram em vitórias importantes sobre as potências coloniais. Sob diferentes formas, os governos dos novos Estados nacionais passaram a adotar políticas econômicas voltadas para o mercado interno e a industrialização por substituição de importações. Em certos casos, tais políticas eram acompanhadas da nacionalização de empresas estrangeiras. A possibilidade de que nacionalismo e socialismo convergissem era encarada como uma séria ameaça aos interesses de longo prazo dos Estados Unidos e seus principais aliados europeus.

Em segundo lugar, alguns governos da periferia começaram a se autoafirmar na diplomacia internacional, buscando constituir um espaço político não alinhado ao dualismo da guerra fria - e procurando tirar proveito dela. A Conferência Afro-Asiática de Bandung (1955) foi o símbolo mais forte dessa movimentação. ${ }^{4}$ Ainda que divididos entre os que advogavam o socialismo e os que advogavam um capitalismo reformado, e compelidos por relações externas bastante diferenciadas, ${ }^{5}$ de modo geral, esses governos, além de condenarem veementemente o colonialismo, reclamavam o "desenvolvimento" de seus países, associando-o ao nacionalismo econômico e à negociação permanente (individual e coletiva) no plano internacional, com a intenção de reduzir a desigualdade de riqueza e poder entre os Estados e dentro das organizações multilaterais.

Em terceiro lugar, a dinâmica da guerra fria modificou-se com a revolução cubana, iniciada em 1959, e o seu grande impacto 
internacional. Para Washington, o processo cubano era um caso de metástase do comunismo na região e constituía um desafio aberto à supremacia americana na sua principal zona de influência.

A segunda grande pressão sobre o BIRD consistia no questionamento crescente do seu papel como agência financeira dedicada ao desenvolvimento. Para ganhar e manter a confiança dos banqueiros de Wall Street, o Banco havia fechado, na prática, o acesso da vasta maioria dos Estados pós-coloniais às fontes internacionais de crédito, uma vez que os mesmos não eram elegíveis aos seus créditos nem à captação de empréstimos nos mercados financeiros. Por outro lado, desde o início das atividades do BIRD, alguns governos de países latino-americanos de renda média, seguidos depois pela Índia, criticavam a ausência, para eles, de crédito sob condições concessionárias, tal como havia sido disponibilizado para a Europa ocidental por intermédio do Plano Marshall. À medida que aumentava a dívida externa dos países da periferia, tornou-se cada vez mais claro que o número de países considerados solventes pelo BIRD poderia diminuir, caso os critérios de elegibilidade para a tomada de empréstimos não fossem alterados (KAPUR et al., 1997, p. 1126-1127). Dois dos maiores clientes do BIRD, Índia e Paquistão, enfrentavam problemas crescentes de solvência e estavam perto do estrangulamento financeiro; para ambos, a URSS — que já havia desenvolvido armas nucleares, lançado o primeiro satélite na órbita terrestre (o Sputnik, em outubro de 1957) e estendia rapidamente a sua diplomacia na África e na Ásia - oferecia assistência técnica e ajuda econômica e militar (LANCASTER, 2007, p. 66). O problema foi identificado pelo governo americano e levou a uma grande operação bilateral de transferência concessionária de crédito, por parte dos EUA, por meio do Development Loan Fund, criado em 1957, e à colaboração estreita entre o BIRD e o Departamento de Estado americano para o lançamento do consórcio de ajuda à Índia, em 1958 (OLIVER, 1995, p. 129; GWIN, 1997, p. 206).

A terceira pressão sobre o Banco era de ordem político-institucional e consistia no fortalecimento da campanha protagonizada por Índia, Chile e Iugoslávia em prol da aprovação do Fundo Especial das Nações Unidas para o Desenvolvimento Econômico (SUNFED). O objetivo da campanha era a criação de uma agência 
da ONU especializada em prover assistência financeira e técnica em termos concessionários que operasse segundo o princípio de um voto por país. Proposto em 1949, o projeto foi aprovado em 1952 pela Assembleia Geral da ONU, a despeito da oposição do governo dos EUA e de outras potências capitalistas (MASON; ASHER, 1973, p. 382-383).

Vale destacar que, em 1951, um grupo de assessoramento chefiado por Nelson Rockefeller foi designado por Truman para recomendar meios que viabilizassem os objetivos do Programa Ponto IV (OLIVER, 1995, p. 44). O grupo salientou a necessidade de se criar, no plano internacional, um instrumento que disponibilizasse algo intermediário entre empréstimos puros, i.e., baseados em termos comerciais, e doações puras, i.e., integralmente subvencionadas, e enfatizou que os EUA deveriam compartilhar com outros Estados a carga financeira da assistência internacional ao desenvolvimento. Nesse sentido, o grupo propôs que os EUA liderassem a criação de duas agências afiliadas ao BIRD: uma dedicada a mobilizar recursos para empréstimos diretos ao setor privado e outra especializada na provisão de créditos concessionários a países pobres, a partir de fundos doados pelos seus membros. Precisamente, aquilo que viriam a ser a Corporação Financeira Internacional (CFI) e a Associação Internacional de Desenvolvimento (AID) em 1956 e 1960, respectivamente (GWIN, 1997, p. 205). Todavia, naquele momento, tais recomendações não foram acolhidas por Washington. Primeiro, porque os EUA estavam envolvidos com a guerra da Coreia (19501953) e enfrentavam um déficit orçamentário crescente. Segundo, porque o establishment americano era refratário a estimular o desenvolvimento dos países da periferia, por meio de créditos concessionários, insistindo no papel primordial do capital privado. Terceiro, existia a visão de que créditos brandos não seriam considerados seriamente como dívida (KAPUR et al., 1997, p. 136). Assim, as propostas foram arquivadas.

Do mesmo modo que Truman, o governo Eisenhower (19531961) era contra a ideia de financiamento concessionário ao Terceiro Mundo e mais ainda que isso se desse por meio de uma agência da ONU. Contudo, embora insistisse na primazia do capital privado como motor do desenvolvimento do Terceiro Mundo, o governo 
americano estava cada vez mais preocupado com a escalada da guerra fria e as tentativas soviéticas de explorar o debate dentro da ONU a tensão emergente entre Norte e Sul (i.e., entre países ricos e pobres). A resposta mais barata e politicamente segura àquela situação era criar um novo ramo do BIRD voltado à concessão de empréstimos para empresas privadas (GWIN, 1997, p. 205-206). Por isso, o governo lançou em 1954 uma proposta, que se materializou dois anos depois, na criação da CFI.

Apesar da manobra, os EUA e seus principais aliados não conseguiram conter a campanha pela criação de uma nova agência de ajuda concessionária. Em outubro de 1958, a ONU habilitou o SUNFED para financiar investimentos (MASON; ASHER, 1973, p. 386; WOODS, 1995, p. 44).

Enquanto a campanha pela viabilização do SUNFED decolava, outro fator pressionou o governo americano: a necessidade do Tesouro de utilizar as reservas em moedas estrangeiras acumuladas desde 1954 pela venda dos excedentes agrícolas aos países da periferia realizadas por meio da Public Law 480. Mais conhecida como "Alimentos para a Paz", a PL 480 tinha o objetivo de viabilizar a venda dos excedentes agrícolas dos EUA e desenvolver mercados comerciais para as exportações americanas de cereais. A lei autorizava a venda de excedentes agrícolas em troca de moedas locais, e não em dólar, o que permitia aos países importadores usarem suas divisas para comprar bens de capital americanos. Além disso, autorizava a doação de alimentos a governos estrangeiros, ampliando o uso da ajuda alimentar como arma política, e permitia a troca de matérias-primas estratégicas à indústria americana por alimentos (BURBACH; FLYNN, 1982; LAPPÉ; COLLINS, 1982; GEORGE, 1978; WINDERS, 2009). Em fevereiro de 1958, uma proposta endossada pelo Senado sugeria que as reservas em moedas não conversíveis passassem para uma nova agência, que as emprestaria como créditos baratos e de longo prazo, para que os países pobres comprassem mais excedentes agrícolas americanos. Dessa maneira, os EUA não apenas se livrariam de parte das suas reservas em moedas fracas, como também fomentariam as suas exportações agrícolas (MASON; ASHER, 1973, p. 393; KAPUR et al., 1997, p. 1127-1129).

Anos 90, Porto Alegre, v. 21, n. 40, p. 493-531, dez. 2014 
A acolhida do Senado, combinada com o crescimento da campanha pelo SUNFED, pressionaram Washington a propor a criação de uma nova agência de ajuda internacional (GWIN, 1997, p. 206). Em meados de 1959, o Tesouro americano propôs a criação da AID. O plano foi aprovado pelos países-membros, em janeiro de 1960. Após a promessa de que teria acesso privilegiado aos créditos da nova agência (que oferecia prazos mais longos e juros mais baixos que os do BIRD), o governo indiano aderiu, enfraquecendo a luta pela viabilização do SUNFED (KAPUR et al., 1997, p. 1128).

No mesmo ano, a AID foi fundada. Do ponto de vista institucional, a Associação era o oposto do que se propusera com o SUNFED. Vinculada ao BIRD, regia-se pelo mesmo sistema desigual de distribuição de voto e passava ao largo dos mecanismos de tomada de decisão da ONU. Ademais, suas atividades seriam financiadas por contribuições periódicas de natureza voluntária e não progressiva, oriundas das negociações e do jogo de interesses entre os países doadores. Já a triangulação proposta pelo Senado, permaneceu letra-morta, o mesmo ocorrendo com a proposta de reembolso dos créditos da AID em moeda local (MASON; ASHER, 1973, p. 393).

Os empréstimos da Associação, ofertados em condições altamente facilitadas (juros muito baixos e prazos de pagamento de 30 a 40 anos), aliviaram a pressão para que o BIRD emprestasse a países pobres considerados de baixa solvabilidade (KAPUR et al., 1997, p. 170). Como previsto, a Índia e o Paquistão - precisamente os dois principais clientes do BIRD ameaçados de insolvência e os dois países vitais para os interesses geopolíticos dos EUA na Ásia - tornaram-se os seus maiores clientes. No início dos anos 1960, ambos passaram a abocanhar sozinhos quase três quartos da carteira de empréstimos da AID (KIRK, 2010, p. 9).

Com a criação da AID, o governo americano e seus principais aliados não apenas conseguiram esvaziar o SUNFED como passaram a contar com mais um instrumento de ajuda externa sob seu controle, num período de acirramento das lutas de libertação nacional e da guerra fria. $\mathrm{Na}$ apresentação da proposta da AID ao Congresso americano, o Secretário do Tesouro, Robert Anderson, ressaltou que os países ricos mostravam, com aquela ação, o "compromisso" 
de ajudar a atender às necessidades de desenvolvimento dos países pobres e "melhorar a sua vida econômica mediante instituições livres" (apud GWIN, 1997, p. 206). Os EUA assumiram uma cota substancial $(42 \%)$ da contribuição inicial da AID e mobilizaram o apoio de outros países ricos. Ao mesmo tempo, a vinculação da AID ao BIRD foi importante para evitar a sua associação direta com a política externa americana. Ademais, a criação da AID forneceu para os EUA um meio adicional de compartilhamento da carga financeira da ajuda externa com as demais potências capitalistas. Juntos, BIRD e AID passaram a constituir o Banco Mundial, nomenclatura adotada desde então.

Em termos mais amplos, a AID fez parte de uma virada efetiva da política estadunidense, operada no final dos anos 1950 e início da década seguinte, em cujo centro estava a decisão de aumentar os desembolsos da ajuda externa bilateral e apoiar o aumento de empréstimos multilaterais como meios para a promoção do desenvolvimento de uma economia "livre e aberta" no Terceiro Mundo. Embora no imediato pós-guerra a ajuda econômica americana tivesse sido concebida e utilizada como instrumento temporário para apoiar governos aliados no curto prazo, durante a segunda metade dos anos cinquenta, os policy-makers de Washington convenceram-se de que o apoio ao desenvolvimento econômico de longo prazo era o único caminho para manter o Terceiro Mundo fora da órbita comunista (LANCASTER, 2007, p. 66).

Seguindo esse mesmo movimento, Washington também impulsionou a fundação, em 1960, do Comitê de Assistência ao Desenvolvimento (CAD). Trata-se de um clube de doadores que reúne os países mais ricos do mundo e é responsável por definir as regras da Ajuda Oficial ao Desenvolvimento (AOD). Sob controle dos EUA, o CAD trabalharia, nas décadas seguintes, em colaboração estreita com o FMI e o Banco Mundial, atrelando, em maior ou menor grau conforme o caso, a concessão da ajuda externa à adoção, pelos países receptores, das pautas de política econômica delineadas pelas instituições de Bretton Woods (SOGGE, 2002, p. 80).

Nenhum presidente americano foi mais entusiasta do uso diplomático do desenvolvimento do que John F. Kennedy (1961-1963). Ao instar a ONU para que proclamasse os anos 1960 como a primeira 
"década do desenvolvimento" - enquanto, com menos alarde, rearticulava o aparato de segurança dos EUA e dava novo impulso às ações encobertas (BANDEIRA, 2006, p. 191-209; FONTANA, 2010, p. 263-265) - Kennedy encarnou o ideal missionário da "liderança americana" e da preservação do seu "modo de vida". Em nome da contenção do comunismo, fortaleceu todas as áreas da assistência externa. No âmbito da ajuda ao desenvolvimento, consolidou os programas existentes dentro da USAID, criou os Corpos de Paz e a Aliança para o Progresso e defendeu no Congresso a ampliação da ajuda econômica por canais bilaterais e multilaterais. Na visão da Casa Branca, a política externa não podia mais se pautar preferencialmente pela dissuasão militar. Segundo o novo enfoque, era preciso modernizar o Terceiro Mundo, estimulando o crescimento econômico, a realização de reformas sociais preventivas e a constituição de regimes liberal-democráticos, a fim de impedir a gravitação soviética e evitar a emergência de regimes políticos que, mesmo não alinhados à URSS, pudessem de algum modo descambar para uma posição hostil aos EUA (GWIN, 1997, p. 207-208; DEZALAY; GARTH, 2005, p. 101-110).

Um dos promotores mais conhecidos do uso da ajuda externa para tais finalidades foi Walt W. Rostow, assessor de segurança nacional dos governos Kennedy e Johnson (1963-1969). Segundo ele, o descontentamento social provocado pela ausência ou insuficiência de desenvolvimento e modernização podia levar ao apoio de doutrinas radicais, como o nacionalismo econômico e o comunismo. Mesmo onde a modernização ocorresse, as tensões provocadas por mudanças sociais e econômicas poderiam também alimentar a adesão a ideologias radicais. Daí a necessidade da ajuda econômica externa para estimular o desenvolvimento e amenizar os seus efeitos colaterais.

A estratégia americana, segundo Rostow (1965), consistia na combinação de três dimensões. Primeira, a ampliação das relações econômicas entre os países "mais desenvolvidos" e os "menos desenvolvidos" para forjar um "moderno sistema de iniciativa privada" na periferia. Segunda, o impulso à modernização tecnológica da atividade agropecuária, considerada vital para o desenvolvimento socioeconômico do campo, a industrialização dos países periféricos e as exportações agrícolas (cereais, sobretudo) dos EUA. Terceira, 
um trabalho amplo, intenso e sistemático de doutrinamento, inclusive mediante a manipulação do "orgulho nacional". De acordo com Rostow, as três dimensões integravam a ação da Aliança para o Progresso (1961-1970), programa de ajuda externa lançado para prevenir a influência que a revolução cubana poderia provocar na América Latina. $\mathrm{O}$ uso desse instrumento foi justificado em termos inequívocos: "A ajuda externa não é, absolutamente, nosso único instrumento nessa luta [...], mas cada dólar colocado [...] é útil e tem influência [...]. Uma redução da ajuda externa simplesmente reduz o poder e a influência efetivos dos EUA no cenário mundial" (ROSTOW, 1965, p. 204). Não por acaso, a ajuda bilateral americana para a América Latina quintuplicou entre 1960-1964, passando de U\$ 157 milhões para U\$ 989 milhões, respectivamente 5\% e 25\% do total (LANCASTER, 2007, p. 69).

A interação entre a política externa dos EUA e a atuação do Banco, que já havia sido estreita durante os anos cinquenta, tornou-se ainda mais intensa, em particular em duas regiões: no sul da Ásia, onde os EUA passaram a desembolsar grandes somas de ajuda financeira ao Paquistão e à Índia, e na América Latina, durante a Aliança para o Progresso. ${ }^{6}$ Numa considerável extensão, a política americana para a instituição era mediada por ações coordenadas dentro dos países entre o Banco Mundial e a USAID (GWIN, 1997, p. 218-219).

\section{O Consórcio de Ajuda à Índia como experiência-piloto}

A Índia não figurava como prioridade da política externa americana em 1947-1948. Porém, essa situação mudou completamente em uma década, à medida que Washington passou a vê-la em uma corrida simbólica pelo desenvolvimento econômico com a China comunista (KIRK, 2010, p. 10-11). Um dos instrumentos mais utilizados pela diplomacia americana foi a ajuda alimentar. O primeiro empréstimo dos EUA para a Índia foi em 1951, para compra de dois milhões de toneladas de trigo. A partir de 1956, sob a PL 480, a Índia passou a comprar alimentos em rupias em termos concessionários. As importações de trigo americano dispararam. Em 1958, sob forte crise do balanço de pagamentos, a Índia tornou-se o primeiro país a 
receber um empréstimo de consórcio internacional coordenado pelo BIRD, que incluía como doadores os EUA, a Europa Ocidental, o Japão e a Austrália. A rigor, Washington era a força mais poderosa daquele arranjo. A atuação do Banco numa área politicamente tão sensível seguiu a orientação dos EUA e somente foi possível devido ao seu apoio. Em troca do socorro, a Índia passou a importar alimentos dos EUA via PL 480 em grande escala até o final dos anos sessenta. Além disso, também foi obrigada a dar incentivos ao capital estrangeiro e a promover medidas de liberalização comercial e industrial (PAYER, 1974, p. 170-183; OLIVER, 1995, p. 125-151; GWIN, 1997, p. 207).

A dependência financeira alavancada pelo consórcio no maior país do Terceiro Mundo que vinha buscando usar a competição Leste-Oeste a seu favor estimulou os doadores a replicar o instrumento. Dois anos depois, um consórcio sob mesmo formato foi criado para o Paquistão, a fim de contrabalançar política e economicamente a Índia. Na sequência, o mesmo modelo foi seguido para as rivais Grécia e Turquia, também por considerações geopolíticas e econômicas relativas a controvérsias em torno da independência do Chipre e da utilização de armas nucleares pelos EUA em ambos os países (KOFAS, 2005, p. 30-31). A partir de 1961, com a criação da Organização para a Cooperação e o Desenvolvimento Econômico (OCDE) e a estruturação do Comitê de Assistência ao Desenvolvimento (CAD), os consórcios internacionais de ajuda financeira multiplicaram-se, tornando-se um instrumento padrão de integração econômica subalterna entre os EUA, os demais países da OCDE e o mundo em desenvolvimento.

\section{O Banco Mundial durante a gestão Woods (1963-1968)}

Nos anos 1950 e mais ainda na década seguinte, multinacionais americanas e europeias instalaram-se no Terceiro Mundo, especialmente em países como Índia, Brasil, México e Indonésia. Grandes países subdesenvolvidos eram os primeiros alvos para a montagem de um setor industrial controlado pelo capital estrangeiro (MAGDOFF, 1978; EVANS, 1980; HOBSBAWM, 1995). No 
contexto da recuperação da economia europeia e do Japão, para os EUA, o modelo de integração assimétrica tinha de evoluir para uma nova fase de capitalismo dependente a partir da multilateralização da ajuda externa e do investimento (KOFAS, 2005, p. 24). Os principais parceiros subalternos jogariam um papel mais ativo nesse processo. Nessa direção, depois de lançar a Aliança para o Progresso, os EUA instaram os seus parceiros subalternos a que fornecessem empréstimos em eurodólares para o Terceiro Mundo e compartilhassem a carga da assistência ao desenvolvimento, o que deu às potências europeias e ao Japão a oportunidade de capturar uma fatia maior do comércio mundial e ter mais alavancagem sobre a política econômica de Estados dentro das suas respectivas zonas de influência.

O impulso à multilateralização da ajuda externa resultou na criação de diversas organizações bilaterais e multilaterais nesse período. Com efeito, a primeira onda de construção institucional havia ocorrido entre 1944 e 1948, quando surgiram, além das instituições de Bretton Woods, a Organização das Nações Unidas para Agricultura e Alimentação (FAO), a Organização das Nações Unidas para a Educação, a Ciência e a Cultura (UNESCO), o Fundo das Nações Unidas para a Infância (UNICEF), a Comissão Econômica e Social para a Ásia e o Pacífico (ESCAP), a Comissão Econômica para a América Latina e o Caribe (CEPAL) e a Organização Mundial da Saúde (OMS). Já a segunda onda, começou em 1957-1958, com a criação do Fundo de Empréstimo ao Desenvolvimento (Development Loan Fund) dos EUA, o Fundo de Desenvolvimento Europeu (European Development Fund), a Comissão Econômica das Nações Unidas para a África (United Nations Economic Commission for Africa) e o primeiro consórcio internacional de assistência à India, sob coordenação do BIRD. Em 1960, surgiram a AID e a Associação Canadense de Desenvolvimento Internacional (Canadian International Development Association); em 1961, o segundo consórcio internacional de ajuda (para o Paquistão), o Ministério da Cooperação na França e na Alemanha, o serviço de cooperação da Suíça, o Fundo de Cooperação Econômica Exterior do Japão (Japan's Overseas Economic Cooperation Fund) e o Comitê Interamericano da Aliança para o Progresso; em 1962, as organizações de ajuda bilateral da Bélgica, 
Dinamarca e Noruega; em 1964, o Banco de Desenvolvimento Africano e, em 1966, o Banco de Desenvolvimento Asiático.

Precisamente nesse período, George Woods, ex-presidente do First Bank Boston, foi indicado pelo governo Kennedy para assumir a presidência do Banco Mundial. Àquela altura, a instituição encontrava-se em condições financeiras bastante sólidas. Não por acaso, a instituição gozava de pontuação máxima "AAA", atribuída pelas agências de credit rating de Wall Street. Contudo, o Banco tinha cada vez menos opções de investimento. Com efeito, o endividamento externo da grande maioria dos seus clientes crescia a um ritmo galopante. O relatório anual da instituição de 1963-1964 indicou que o endividamento público externo dos países em desenvolvimento aumentara, em média, a uma taxa anual de 15\% entre 1955 e 1962 (MASON; ASHER, 1973, p. 221, nota 39). Em 1965, o relatório anual do Banco ressaltou que a queda dos preços das matérias-primas não havia sido compensada pelo aumento geral do volume exportado, nem pelo afluxo de empréstimos, doações e capital, dado o volume ainda maior de pagamentos da dívida externa e a repatriação de lucros das empresas multinacionais. Entre 1962-1964, onze países - todos grandes clientes do Banco - concentravam pouco mais da metade da dívida externa: Índia, Brasil, Argentina, México, Egito, Paquistão, Turquia, Iugoslávia, Israel, Chile e Colômbia (BANCO MUNDIAL, 1965, p. 57; TOUSSAINT, 2006, p. 176). Entre 1957 e 1969, credores internacionais - na maioria dos casos, sem a mediação formal do Banco — realizaram vinte e uma operações de renegociação das dívidas, reprogramando os pagamentos. ${ }^{7}$ Por outro lado, no início da década de 1960, começou a haver uma transferência líquida negativa de recursos de diversos clientes para o BIRD (PAYER, 1991, p. 10-15; RICH, 1994, p. 80). Em resumo, o BIRD viu-se diante da escassez de prestatários considerados solventes, o que era um problema sério não apenas porque se tratava de uma organização baseada na realização de empréstimos, mas também por razões políticas e de imagem (AYRES, 1983, p. 3; KAPUR et al., 1997, p. 177). Afinal, estava-se em plena "década do desenvolvimento" e o número de países-membros do Banco - que já havia subido de 45 para 75 entre 1949 e 1962, graças à criação da AID, 
- não parava de aumentar, assim como aumentava o número de instituições bilaterais e multilaterais capazes de fornecer créditos.

A resposta da gestão Woods a tal situação consistiu, de um lado, na suavização das condições de pagamento e, de outro, o aumento da concessão de empréstimos. Tratava-se de expandir a "solvência" dos seus clientes, uma vez que a mesma era cada vez mais encarada como uma "função do crescimento", ligada ao aumento da "capacidade de absorção" de capital estrangeiro (MASON; ASHER, 1973, p. 471). Para operacionalizar essa orientação, o Banco abrandou os critérios de solvência e passou a valorizar outros indicadores para a autorização de empréstimos, como o potencial de crescimento e o tipo de política econômica implementada, o que, por sua vez, aumentou a importância da "assistência técnica" no modus operandi do Banco. Por outro lado, para alguns países politicamente estratégicos, como a Índia, o Banco começou a conceder empréstimos para amortecer crises nos respectivos balanços de pagamentos, normalmente sob a forma de empréstimos para importações industriais. Com tudo isso, o Banco Mundial imiscuiu-se cada vez mais na vida econômica dos seus clientes durante a gestão Woods (RICH, 1994, p. 80; CAUFIELD, 1996, p. 91-94). Do mesmo modo, a entidade forneceu empréstimos em abundância para Estados cujos governos ditatoriais eram aliados dos EUA — Nicarágua, sob Somoza; Brasil, depois de 1964; Espanha, sob Franco; Portugal, sob Salazar; Indonésia, sob Suharto; Zaire, sob Mobutu; África do Sul, sob o apartheid, entre outros (PAYER, 1974; KOFAS, 2005; TOUSSAINT, 2006, p. 83-98). Por tudo isso, entre 1963 e 1968, houve uma expansão notável do Banco Mundial em todas as áreas, como mostra a tabela 2. 
Tabela 2 - Tamanho do Banco Mundial (BIRD e AID): crescimento por períodos - de 1948-1949 até 1968-1969

\begin{tabular}{c|c|c|c}
\hline \multirow{2}{*}{} & \multicolumn{3}{|c}{ Anos fiscais (b) } \\
\cline { 2 - 4 } & $\mathbf{1 9 4 8 - 4 9}$ & $\mathbf{1 9 5 9 - 6 0}$ & $\mathbf{1 9 6 8 - 6 9 ~ ( c ) ~}$ \\
\hline Despesas administrativas (a) & 35 & 81 & 261 \\
\hline Staff total & 414 & 657 & 1859 \\
\hline Staff de alto nível & & 270 & 829 \\
\hline Número de países-membros & 47 & 68 & 109 \\
\hline Número de clientes & 4 & 21 & 51 \\
\hline Número de empréstimos (d) & 7 & 44 & 103 \\
\hline Compromissos financeiros (a) & 1.093 & 4.100 & 7.194 \\
\hline
\end{tabular}

Fonte: Kapur et al. (1997, p. 186).

Milhões de dólares. Valores corrigidos para 1993.

(a) Anos fiscais encerrados em 30 de junho.

(b) A maior parte dos compromissos financeiros durante 1968 e início de 1969 podem ser atribuídos à gestão Woods.

(c) Inclui empréstimos do BIRD desde o ano fiscal de 1947, da CFI desde 1957 e da AID desde 1961.

Entre 1961 e 1969, os empréstimos do Banco aumentaram à razão de $10,4 \%$ ao ano. O orçamento administrativo mais do que triplicou. O staff de alto nível (profissional) cresceu 13\% ao ano, mais rápido do que em qualquer outra década, superando o peso dos engenheiros pelo primado dos economistas (KAPUR et al., 1997, p. 187-188). Ademais, o Banco iniciou operações em 50 novos países, dos quais 27 estavam na África Subsahariana, dez no norte da África e Oriente Médio, sete na América Latina e seis na Ásia. A tabela 3 mostra o volume de desembolsos e identifica quanto e onde o Banco alocou recursos. 
O banco mundial nos anos 1960

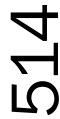

\begin{tabular}{|c|c|c|c|c|}
\hline & $\begin{array}{l}\text { ज्ञ } \\
\stackrel{0}{0}\end{array}$ & 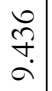 & $\begin{array}{l}\text { ڤ్రి } \\
\text { - }\end{array}$ & $\begin{array}{l}\hat{\sigma} \\
\stackrel{+}{+}\end{array}$ \\
\hline & 是 & $\begin{array}{l}\overrightarrow{\mathrm{N}} \\
\overrightarrow{\mathrm{N}}\end{array}$ & $\stackrel{n}{\sim}$ & 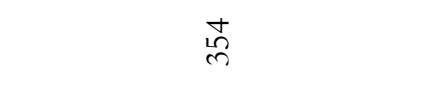 \\
\hline & $\underset{\underline{A}}{\stackrel{\theta}{a}}$ & 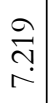 & $\begin{array}{l}\underset{+}{J} \\
\stackrel{+}{*}\end{array}$ & $\stackrel{\mathscr{m}}{\underset{F}{F}}$ \\
\hline $\mathbb{u}_{0}$ & 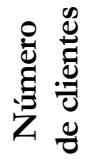 & $\approx$ & $\stackrel{0}{\sim}$ & $\stackrel{\mathscr{F}}{f}$ \\
\hline 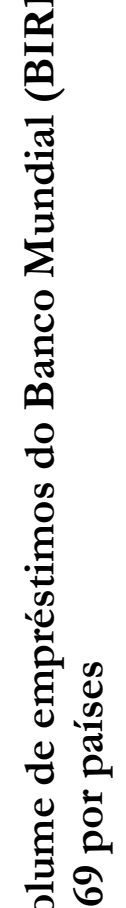 & 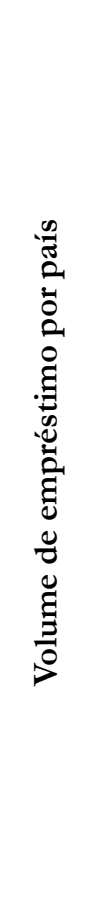 & & 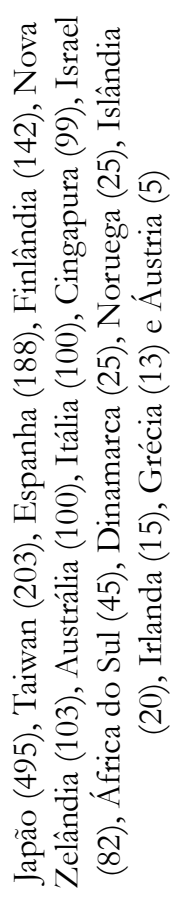 & 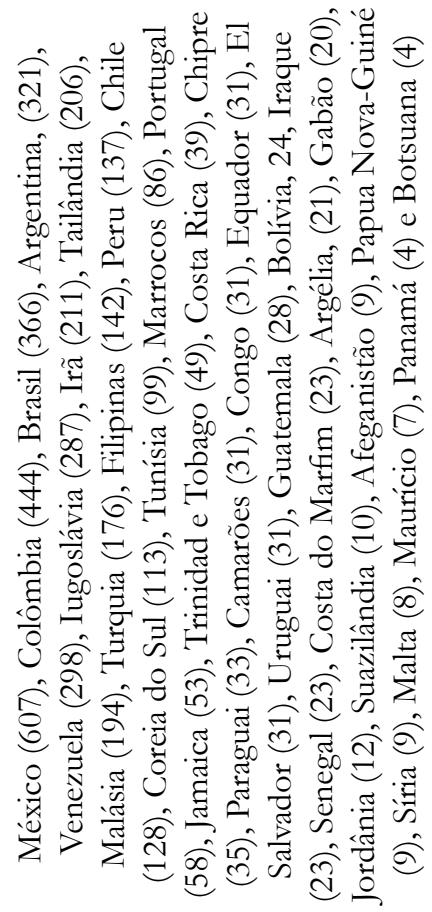 \\
\hline 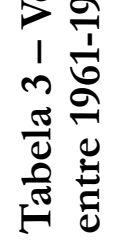 & 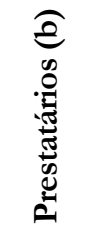 & 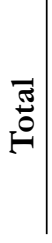 & 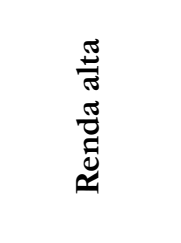 & 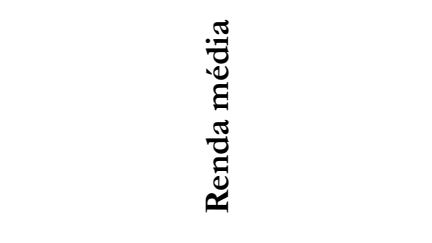 \\
\hline
\end{tabular}

Anos 90, Porto Alegre, v. 21, n. 40, p. 493-531, dez. 2014 


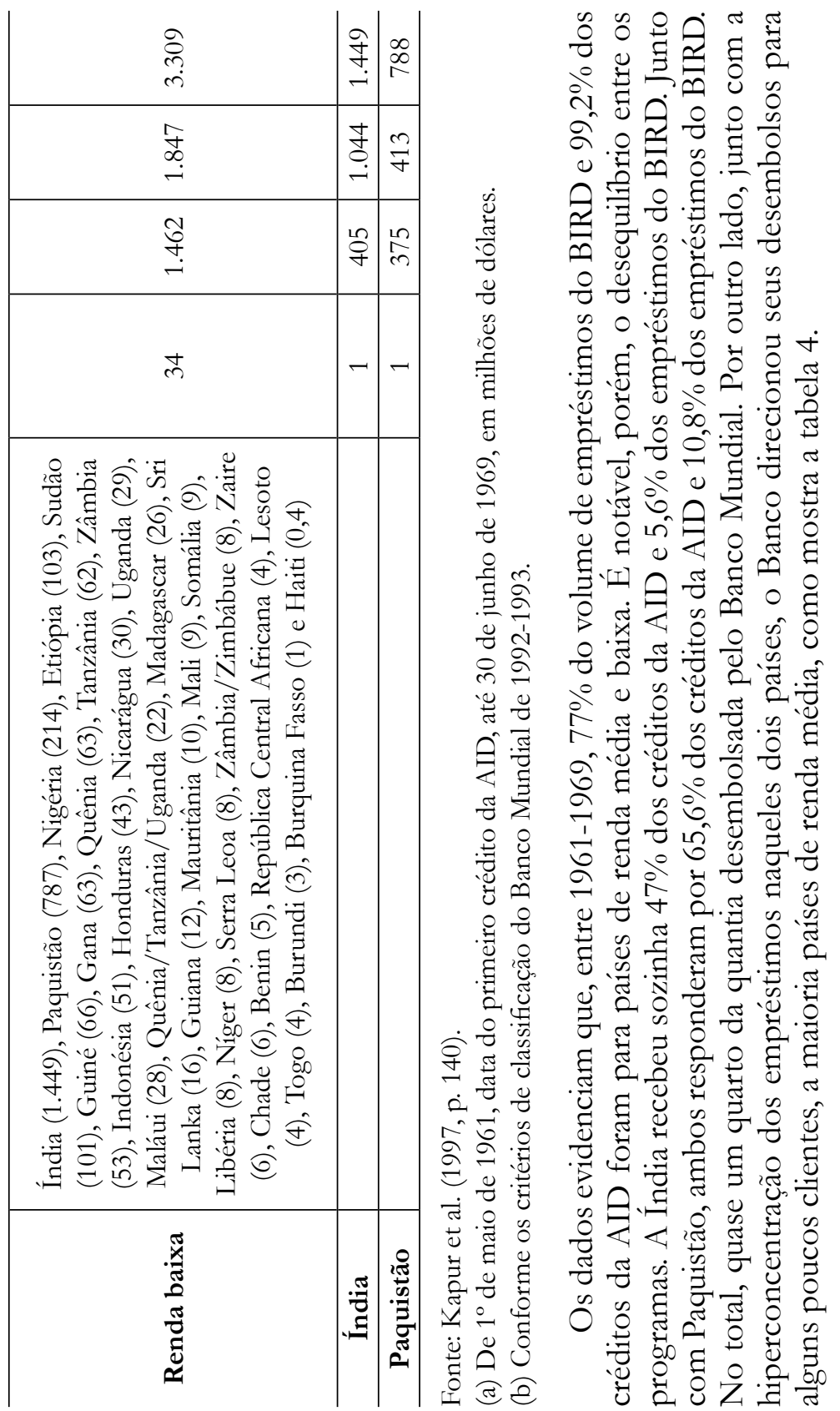


O banco mundial nos anos 1960

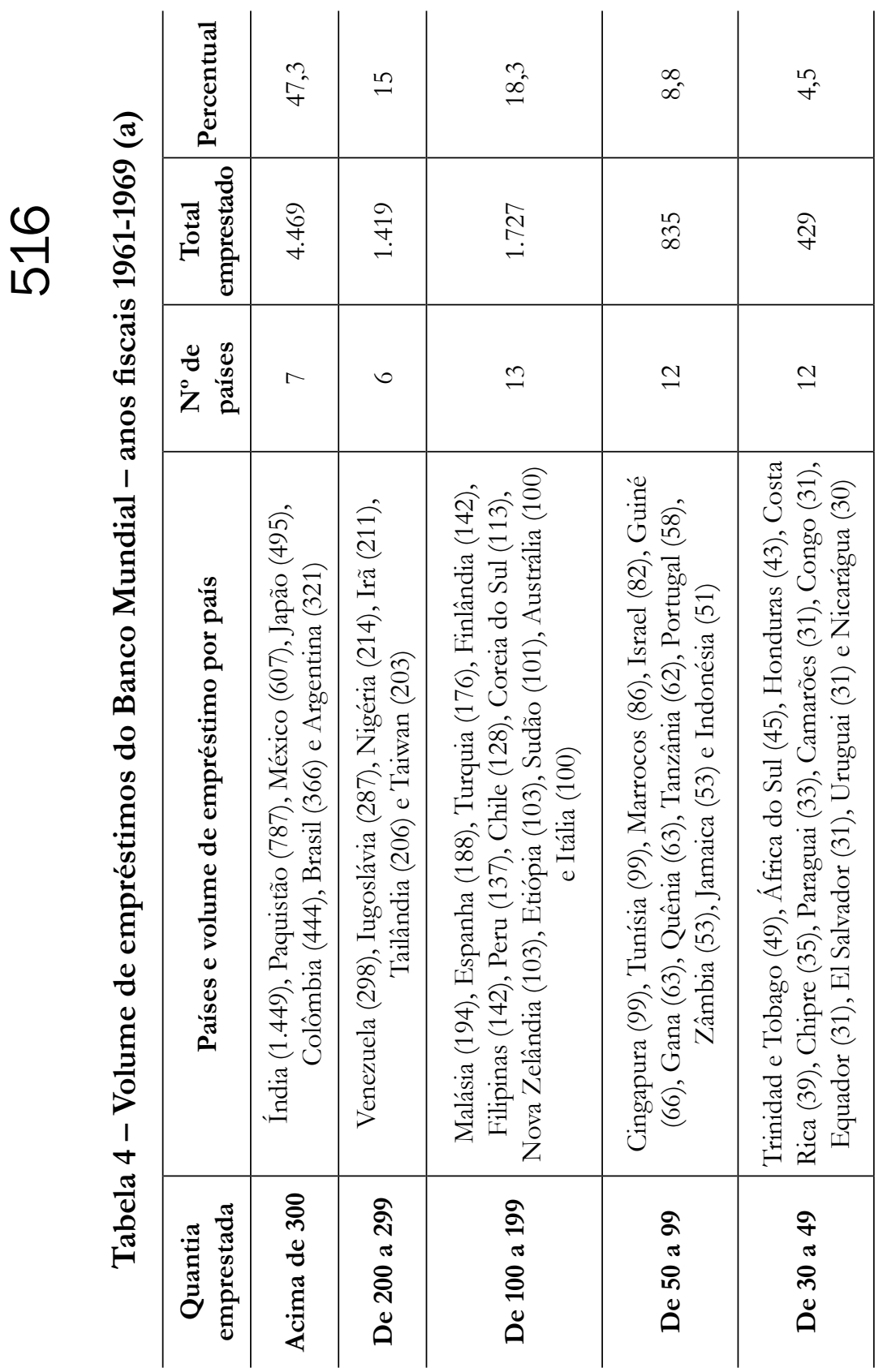

Anos 90, Porto Alegre, v. 21, n. 40, p. 493-531, dez. 2014 
João Márcio Mendes Pereira

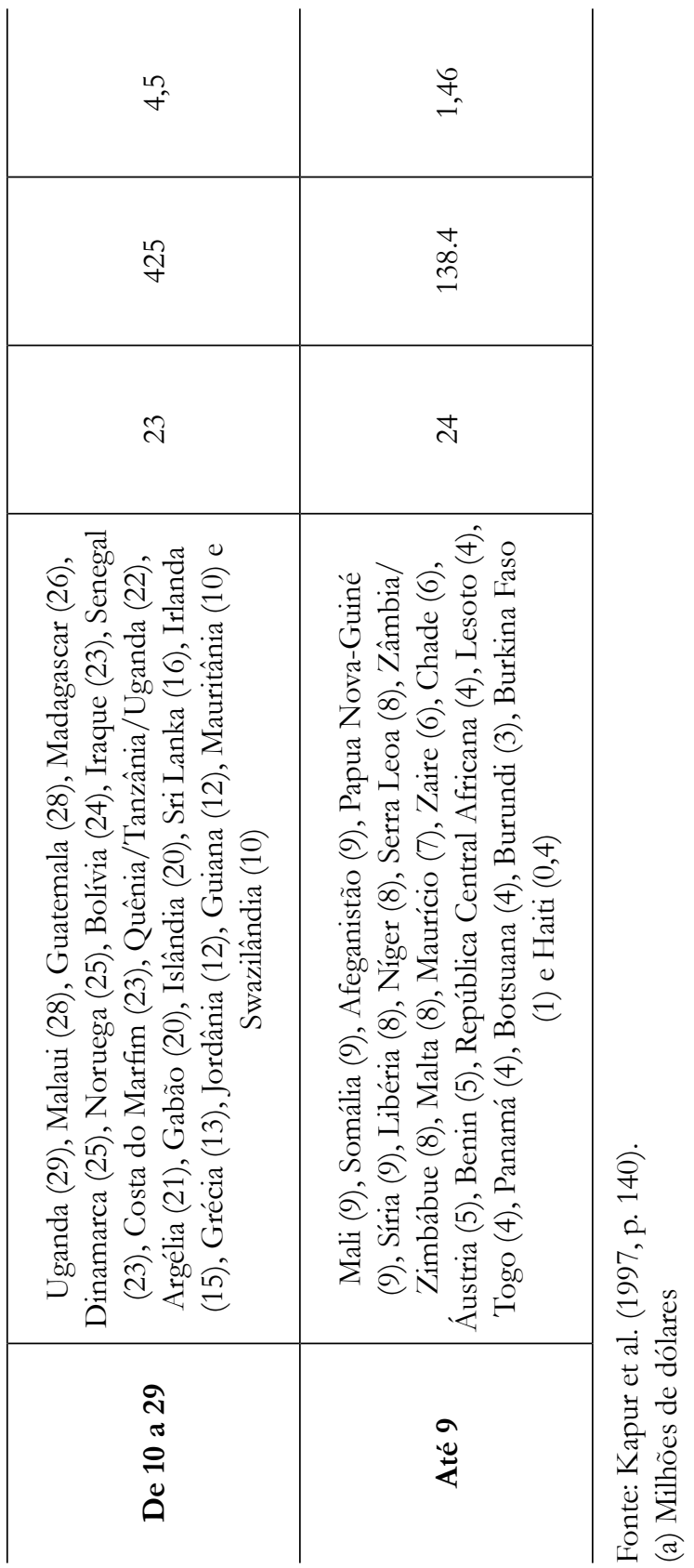


Tão importante quanto o aumento do portfólio foi a sua diversificação setorial. Os empréstimos para a agropecuária cresceram consideravelmente, em particular, para projetos não vinculados à irrigação e para instituições financeiras nacionais de fomento. Começaram os créditos para educação, abastecimento de água e saneamento básico. A tabela 5 informa o volume de empréstimos por setor.

Tabela 5 - Alocação setorial dos empréstimos do Banco Mundial (BIRD e AID) - anos fiscais 1961-1969

\begin{tabular}{c|c|c|c|c}
\hline Setores & BIRD & AID & Total & $\mathbf{\%}$ \\
\hline Transporte & 2.372 & 714 & 3.086 & 32.7 \\
\hline Energia & 2.555 & 141 & 2.696 & 28.5 \\
\hline Agricultura & 764 & 395 & 1.159 & 12.2 \\
\hline Finanças & 768 & 40 & 808 & 8.5 \\
\hline Empréstimos de programa (b) & 0 & 555 & 555 & 5.8 \\
\hline Indústria & 327 & 7 & 333 & 3.5 \\
\hline Telecomunicações & 158 & 119 & 277 & 2.9 \\
\hline Educação & 92 & 152 & 244 & 2.5 \\
\hline Abastecimento de água e saneamento & 99 & 66 & 165 & 1.7 \\
\hline Mineração & 85 & 0 & 85 & 0.9 \\
\hline Empréstimos não setoriais (c) & 0 & 29 & 29 & 0.3 \\
\hline Total & 7.220 & 2.218 & 9.437 & 100 \\
\hline
\end{tabular}

Fonte: Kapur et al. (1997, p. 141)

(a) De $1^{\circ}$ de maio de 1961 a 30 de junho de 1969, em milhões de dólares

(b) Créditos para importação industrial para Índia e Paquistão

(c) Assistência técnica e créditos para importação comercial

Os dados disponíveis permitem dimensionar as mudanças operadas pela gestão Woods. Os empréstimos para países de renda média e baixa realizados entre 1948 e 1961 totalizaram US\$2,3 bilhões, dos quais US $\$ 2$ bilhões $(86,9 \%$ do total) foram para energia e transporte e apenas US\$ 100 milhões (5\% do total) foram destinados para agricultura e irrigação (KAPUR et al., 1997, p. 86). Nenhum centavo foi autorizado para educação, saúde e outros setores considerados não 
lucrativos. Já entre os anos de 1961 e 1969, o volume de empréstimos triplicou, chegando a US $\$ 7,7$ bilhões, dos quais $12,2 \%$ foram direcionados para agropecuária e irrigação e 4,2\% para educação, abastecimento de água e saneamento básico. Mesmo assim, 61,2\% do total foram para energia e transporte.

Até o início dos anos 1960, o programa do Banco para a agricultura havia sido modesto e fazia parte da sua ênfase em infraestrutura, resumindo-se a grandes projetos de irrigação e drenagem intensivos em capital. Em certos casos, projetos de irrigação e energia eram a mesma coisa. Contudo, proporcionalmente, os empréstimos para agricultura foram os que mais cresceram durante a gestão Woods. O principal fator que empurrou o Banco nessa direção foi a "revolução verde". Com o apoio da Fundação Rockefeller, experimentos realizados em 1943 no México desenvolveram sementes híbridas de trigo cuja alta produtividade dependia de condições ótimas de irrigação e do uso intensivo de pesticidas, fertilizantes químicos e máquinas agrícolas produzidos por agroindústrias americanas e europeias. Logo vieram experimentos similares com sementes de milho e arroz (PERKINS, 1997). No início dos anos 1950, a Fundação Rockefeller associou-se à Fundação Ford e à USAID com o propósito de formar técnicos e economistas especializados para difundir as novas variedades na Índia, patrocinando a criação de centros de pesquisa agrícola em diversos países na década seguinte. $\mathrm{O}$ primeiro foi o Instituto Internacional de Investigação sobre o Arroz (IRRI), nas Filipinas, em 1960. Depois vieram o Centro Internacional de Melhoramento de Milho e Trigo (CIMMY'T), no México, em 1966, o Instituto Internacional de Agricultura Tropical (IITA), na Nigéria, em 1967, e, no mesmo ano, na Colômbia, o Centro Latino-Americano para Agricultura Tropical (CIAT). Os quatro tinham em comum a missão de aumentar a produtividade agrícola nos países da periferia e, graças às fundações, contavam com recursos técnicos de ponta sem sobrecarregar a política externa americana (KAPUR et al., 1997, p. 399).

No mesmo período, grandes empresas de fertilizantes começaram a pressionar a USAID e os organismos internacionais, como o Banco Mundial, para que financiassem a difusão do pacote tecnológico da revolução verde na Ásia, na África e na América Latina 
(BURBACH; FLYNN, 1982, p. 122). A produção das novas variedades dependia de um sofisticado e caro sistema de irrigação e da utilização de insumos industriais cuja eficiência máxima se dava a partir de certa escala, o que beneficiava os produtores mais ricos, mais instruídos e detentores das melhores terras (GEORGE, 1978, p. 111; LAPPÉ; COLLINS, 1982, p. 115-22). O acesso ao crédito agrícola e aos serviços de assistência técnica tornou-se indispensável. Para viabilizá-lo, fundos públicos nacionais e estrangeiros passaram a ser canalizados diretamente para a produção das novas variedades, fortalecendo elites agrárias e empresas agroquímicas a expensas do campesinato (PAYER, 1982, p. 207-245). Enquanto a Europa subsidiava os seus agricultores, os EUA, os países europeus e o Banco Mundial pressionavam os países subdesenvolvidos a adotarem a revolução verde mediante a compra de máquinas e insumos químicos produzidos nos países avançados. Isso contribuiu para o aumento da produção, mas também da dívida externa e da crescente dependência alimentar (KOFAS, 2005, p. 24; SHIVA, 1991, p 171-194).

Ademais, o aumento da produção agrícola era uma questão politicamente urgente para Washington e o Banco Mundial. Estava em voga nesse circuito o neomalthusianismo e o temor de uma "crise alimentar", provocada pelo aumento mais acelerado da população em relação ao da produção de alimentos no Terceiro Mundo, em particular no sul da Ásia. Nessa época, ganhou relevo junto ao staff do Banco a tese de que os agricultores "tradicionais" eram receptivos a incentivos econômicos e predispostos à otimização da produção segundo critérios de rentabilidade capitalistas. O trabalho de Schultz (1964) foi um marco dessa nova visão e deu racionalidade econômica à elaboração de projetos voltados à modernização técnica de franjas específicas do campesinato — sobretudo, pequenos proprietários e arrendatários (KAPUR et al., 1997, p. 386; OLIVER, 1995, p. 165).

Ao longo dos anos 1960, o Banco não apenas cresceu e diversificou a alocação setorial de seus empréstimos, mas também ampliou a sua gravitação na assistência internacional ao desenvolvimento. A concertação entre o Banco e os doadores bilaterais e multilaterais teve impulso com o primeiro consórcio internacional de ajuda direcionado à Índia em 1958. Posteriormente, em 1966, o Banco 
prescreveu àquele país uma série de medidas econômicas. As mais importantes eram a guinada da ênfase na indústria pesada para a agricultura, a desvalorização da rupia e o fim dos subsídios à exportação. A desvalorização da moeda tornou-se a medida mais importante, simbolicamente. A principal preocupação do Banco era com o baixo nível das reservas estrangeiras da India, o que comprometia a manutenção das importações de produtos agrícolas e fertilizantes americanos. Em troca, informalmente o Banco prometeu conseguir um aumento substancial da ajuda externa ao país. Àquela altura, a necessidade de alimentos importados e a escassez de divisas haviam tornado a Índia fortemente dependente dos EUA, do Banco Mundial e do FMI. Em junho de 1966, o governo anunciou a desvalorização da moeda em 36,5\%. A reação interna contra a medida foi ampla. Os EUA e as instituições de Bretton Woods foram identificados como responsáveis pelo que foi visto como um ato de agressão à soberania nacional. Buscando apoio nos partidos de oposição, Indira Gandhi acabou abandonando o programa de reformas acordado com o Banco Mundial. Depois da crise de 1966, o Banco adotou uma política de empréstimos independentemente da política americana de curto prazo para a Índia, ampliando a carteira com o seu principal cliente. Desse modo, até o final dos anos 1980, o Banco forneceria cerca de $65 \%$ da assistência externa ao país, enquanto a ajuda bilateral americana despencava. Por outro lado, o Banco Mundial adaptou diversas propostas prescritas para a Índia em um programa de reforma econômica para a Indonésia, em que a ditadura de Suharto não enfrentava os mesmos constrangimentos internos (KIRK, 2010, p. 14-22; KAPUR et al., 1997, p. 466-471).

A despeito da diversificação setorial e da extensão da atuação do Banco Mundial para países pobres, a visão predominante dentro da instituição sobre os benefícios gerais decorrentes do crescimento econômico não se alterou. ${ }^{8}$ No início dos anos 1960 , o credo do desenvolvimento estava em alta, alimentado pela onda expansiva do pós-guerra que incluía não apenas a Europa e o Japão, mas também alguns países da periferia. A crença no poder da tecnologia e da ciência parecia inexpugnável e sua aplicação agora não focalizava apenas a indústria, mas também, e cada vez mais, a agricultura, na esteira dos resultados iniciais da revolução verde. Mais do que nunca, 
o desenvolvimento era visto como uma função direta do investimento físico. Nesse sentido, os conceitos e modelos explicativos em voga (bigpush, take-off, entre outros) sintonizavam e harmonizavam a doutrina econômica produzida no mainstream acadêmico americano, com a pregação de Washington, para que os países do Terceiro Mundo absorvessem mais ajuda econômica e capital estrangeiro (KAPUR et al., 1997, p. 146-148). Parte do establishment acadêmico americano, normalmente em associação com grandes fundações filantrópicas, produzia análises, teorias e quadros para fomentar esse tipo de visão. Destacou-se, p.ex. o Centro de Estudos Internacionais do MIT, criado em 1952 com fundos da CIA, por iniciativa de Rostow (LATHAM, 2000, p. 53-57).

Contudo, apesar da obsessão com o crescimento econômico, a escalada da guerra fria impôs ao Banco Mundial a realização de ajustes conceituais. Assim, convertido em questão política, ao longo da década, o desenvolvimento deixou de ser sinônimo de aumento da capacidade produtiva, independentemente da localização, para se tornar algo cujo significado se aproximava da redução da desigualdade entre os países (KAPUR et al., 1997, p. 140). O mapa global era redesenhado então em dois eixos, superpondo-se à divisão LesteOeste a divisão Norte-Sul entre nações ricas e pobres. Dentro do Banco, a diferença relativa de renda entre os países tornou-se um critério aceito para alocação ou racionamento de créditos brandos. A ideia de pobreza relativa ganhou certa adesão e a versão mais elementar desse conceito, a renda per capita, tornou-se a referência padrão da AID (ibid, p. 191-194).

Ainda que a ideia, cogitada em 1963, de que a AID financiasse não apenas os mais pobres no plano internacional, mas também no plano nacional, fosse desconsiderada (ibid, p. 197), na prática, a evocação à "pobreza" começou a ser usada fracamente como critério interno para justificar a autorização de empréstimos "sociais". Dado que a visão convencional do Banco se mantinha inabalada, projetos para agropecuária, educação e abastecimento de água, ainda que modestos e incipientes, acabavam carregando a tensão entre a sua natureza não estritamente produtiva e a regra de que todos os empréstimos e aconselhamentos do Banco deveriam ser orientados para a maximização do crescimento econômico, 
a geração de lucros para o Banco e a demanda por importações (ibid, p. 173, p. 381).

A agricultura tornou-se o setor operacional em que mais se exploravam as ligações entre o aumento da produtividade e a redução da pobreza, embora o pêndulo se inclinasse à primeira e nenhuma ação tenha sido tomada em prol da principal bandeira daquele período nesse âmbito - a reforma agrária. No caso da educação, durante a década de sessenta, o Banco permaneceu em larga medida refratário à ascensão da teoria do capital humano, encarando a atividade basicamente como gasto social, e não como investimento econômico (ibid, p. 206-207). Mesmo assim, o Banco buscou financiar modalidades consideradas mais produtivas de educação, em particular, o ensino técnico, com destaque para o ensino agrícola e extensionista de tipo formal ou informal. A educação fundamental de massa era explicitamente rejeitada (ibid, p. 201-202). Como os sistemas de ensino eram predominantemente públicos, não engendravam a cobrança de taxas e, portanto, não eram considerados pelo Banco como autofinanciáveis. Não por acaso, $78 \%$ dos empréstimos para a educação efetuados até 1968 procederam da AID. Quanto aos projetos de abastecimento de água, apesar de figurarem como itens "sociais" no rol de projetos produtivos, o fato é que a maior parte dos empréstimos para essa finalidade veio do BIRD. Com efeito, as exigências de geração de receita e cobrança de taxas transformaram tais projetos em produtos financiáveis. A prioridade não era a saúde pública.

Ao final dos cinco anos da gestão Woods, o Banco havia concedido mais empréstimos do que nos seus primeiros dezesseis de atividade. Os critérios mais conservadores para concessão de empréstimos para projetos continuaram a ser tomados como referência, e a imagem do Banco como emprestador exigente e solidamente baseado no mercado permaneceu incólume. Todavia, houve uma suavização operacional na sua orientação creditícia, em virtude da necessidade de dar respostas às mudanças geopolíticas ocorridas cenário internacional. Além de aumentar os desembolsos para a agricultura, na esteira da revolução verde, o Banco iniciou operações nas áreas educacional e urbana. Em particular, aumentou bastante o componente de assistência técnica, ampliando a sua gravitação na vida econômica e política dos países-membros. 
Concomitantemente, prosseguiu o declínio da importância relativa do mercado americano como fonte de recursos para o Banco. Em meados dos anos 1960, pela primeira vez, o Tesouro brevemente negou ao Banco o acesso ao mercado financeiro doméstico, com o objetivo de enfrentar o déficit no balanço de pagamentos. Isso forçou o Banco a captar a maior parte dos seus fundos em outras praças. No final da década, mais da metade dos empréstimos em dólar tomados pelo Banco veio de títulos comprados por investidores de fora dos EUA (GWIN, 1997, p. 203). O crescimento das economias alemã e japonesa e a força das suas moedas desempenharam um papel importante na sustentação dessa mudança. Ainda que o dólar permanecesse como a moeda principal das suas operações, o financiamento do Banco deixou de depender exclusivamente de Wall Street.

A primeira reposição de fundos da AID ocorreu ainda no governo Kennedy, num contexto de expansão da política de assistência externa. Os EUA defenderam que as contribuições quintuplicassem, chegando à soma de US\$ 1,5 bilhão ao ano durante um triênio, ao mesmo tempo em que procuraram reduzir a cota americana de 42,3 para $33,3 \%$. Ou seja, enquanto dava prioridade ao seu programa bilateral, o governo tentava aumentar também os instrumentos multilaterais de ajuda externa, porém aliviando a sua própria carga financeira. Diante da resistência de outros países doadores, os EUA decidiram por uma reposição bem menor, de US $\$ 750$ milhões, e uma pequena redução da sua cota, que caiu para 41,8\% (GWIN, 1997, p. 208).

As negociações para a segunda reposição, iniciadas em 1966, foram mais difíceis (KAPUR et al., 1997, p. 211). O governo americano, então, tomava medidas para controlar a inflação, reduzir a evasão de dólares e impedir ou minimizar a desvalorização da moeda (OLIVER, 1995, p. 228-229). Ademais, para financiar a guerra do Vietnã e a corrida armamentista, o governo era obrigado a cortar programas domésticos e aumentar impostos. Crescia nos EUA a "fadiga da ajuda", i.e., a queda do apoio político, sobretudo no Congresso, à ajuda externa, cada vez mais considerada um instrumento ineficiente para a promoção dos interesses americanos no mundo (LANCASTER, 2007, p. 70).

Anos 90, Porto Alegre, v. 21, n. 40, p. 493-531, dez. 2014 
Para alavancar o movimento expansivo do Banco Mundial, Woods propôs uma reposição de um bilhão de dólares, com a qual o Executivo concordou em princípio (OLIVER, 1995, p. 230). As negociações com os demais doadores foram encerradas e a proposta foi encaminhada ao Congresso dos EUA para aprovação. Woods deixou a presidência do Banco no início de 1968, deixando ao seu sucessor, Robert McNamara - Secretário de Defesa dos EUA desde 1961 — a tarefa de concluir o processo. A proposta enfrentou certa resistência no Congresso e as disputas se arrastaram, provocando o atraso na aprovação dos recursos e obrigando outros doadores a aportarem fundos para evitar uma suspensão temporária dos créditos da AID. Como argumentou Gwin (1997, p. 209), a partir da segunda reposição, emergiu um padrão oriundo de pressões ora do Legislativo - cada vez mais atuante — , ora do Executivo, pelo qual a cada rodada de negociação os EUA exigem concessões para autorizar a sua contribuição à AID e/ou atrasam a liberação dos fundos. Assim, enquanto o BIRD cada vez mais captava recursos em praças financeiras fora dos EUA, tornando-se financeiramente menos dependente de Wall Street, a AID abria-se às vicissitudes da disputa política em Washington (Executivo e Congresso) e entre os EUA e os demais doadores - dinâmica que se intensificaria nas décadas seguintes e seria utilizada pelos EUA para, paradoxalmente, aumentar a sua própria influência no Banco.

\section{Considerações finais}

Sobre as ruínas da II Guerra Mundial, a dependência em relação ao mercado financeiro americano impôs ao BIRD a necessidade de conquistar a confiança dos investidores de Wall Street para se viabilizar como ator financeiro. Isso modelou fortemente a trajetória da entidade nos seus primeiros vinte anos de funcionamento, em particular a sua política de empréstimos para projetos de desenvolvimento.

Em resposta a um conjunto de pressões políticas e econômicas durante a segunda metade dos anos 1950, o BIRD — sob o patrocínio do seu acionista mais poderoso, os EUA — sofreu um processo de 
ampliação, que se materializou na criação de duas novas entidades afiliadas: a CFI e AID. Graças à AID, o Banco aprofundou a sua relação com clientes estratégicos na África e, sobretudo, na Ásia.

Durante a maior parte dos anos 1960, o credo internacional no desenvolvimento esteve no auge. $\mathrm{O}$ movimento expansivo do Banco naquele período envolveu o aumento extraordinário do número de clientes, do volume de empréstimos, do tamanho do orçamento administrativo e do staff. Além disso, ela abarcou também o início dos empréstimos para setores antes não financiáveis, como educação, abastecimento de água e saneamento básico. Igualmente, houve um crescimento significativo de empréstimos para agricultura, associados ao deslanche da revolução verde e ao foco em áreas politicamente sensíveis, como a Índia e o Paquistão. Mesmo assim, a fatia maior da sua carteira permaneceu direcionada para o mesmo de sempre: energia e transporte.

As mudanças efetuadas nos anos 1960 criaram condições para que, na década seguinte, o Banco tivesse uma projeção internacional muito superior e de novo tipo, sob a gestão de Robert McNamara (1968-1981). Em retrospecto, conclui-se que os anos 1960 constituíram uma fase de transição entre o BIRD dos anos 1950 - que emprestava mais para reconstrução do que para desenvolvimento; que era absolutamente dependente do mercado de capitais americano; que investia praticamente nada em pesquisa; que estava fora da África Subsahariana e de parte importante da Ásia; que era relativamente pouco envolvido com a agropecuária e que não tinha qualquer entrada financeira ou intelectual em setores fundamentais como educação e saúde - e o Banco Mundial (BIRD e AID) dos anos 1970, convertido indiscutivelmente na principal agência internacional de desenvolvimento. Esse novo Banco teria o BIRD muito menos dependente de Wall Street, mas a AID altamente dependente das vicissitudes políticas de Washington. Por outro lado, sob McNamara, o Banco estenderia a sua gravitação para toda a periferia capitalista, na condição de principal financiador público internacional da revolução verde e líder intelectual e político do "combate à pobreza" no mundo. Tamanha transformação não teria sido possível sem o estiramento institucional e a mudança incremental operados entre 1960 e 1968. 


\section{THE WORLD BANK IN THE 1960S}

Abstract: The article discusses the history of the World Bank in the 1960s, linking it with the international economics and American foreign policy. Identifies the organizational profile built in the 1950s, deeply marked by financial dependence on Wall Street, and analyzes a set of international political and economic pressures that eventually impose the realization of changes in organizational structure and credit policy of the entity. Moreover, it characterizes the major lines of the Bank's accelerated growth in the 1960s in terms of loan volumes, number of client States, administrative budget and size of employee numbers. It also discusses the relative diversification of the financed projects' profile.

Keywords: World Bank. United States. Cold war. Green revolution. U.S. foreign aid.

\section{Notas}

${ }^{1} \mathrm{O}$ BIRD é uma instituição interestatal, de modo que os seus membros são Estados nacionais. Para ser membro do BIRD, é necessário, primeiro, fazer parte do FMI. O BIRD concede empréstimos a Estados elegíveis como clientes. Todos os clientes são membros do Banco, mas nem todos os membros são clientes. Ao longo da sua história, o BIRD nunca emprestou para Estados Unidos, Inglaterra, Alemanha e Canadá. Cerca de 80\% dos recursos da instituição advêm da venda de seus próprios títulos em mercados de capital, e seus empréstimos são concedidos em condições próximas às do mercado financeiro internacional. Os demais $20 \%$ constituem o lastro das suas operações, denominado "capital geral", que é aportado pelos Estados-membros, em proporções desiguais, e só pode ser aumentado após negociações entre eles. O poder de voto no BIRD - assim como no FMI - é desigual e proporcional ao capital aportado por cada Estado-membro, quantia que é negociada politicamente entre os Estados. Por um acordo informal vigente desde 1944, o presidente do Banco Mundial é sempre um cidadão americano indicado pelos Estados Unidos.

${ }^{2}$ Entre 1947 e 1954, o BIRD emprestou, para a fins de "reconstrução", tão somente US\$ 800 milhões. O aporte de recursos dos EUA era vital para a viabilização do BIRD, porque representava mais de um terço da subscrição do seu capital geral e era o único componente plenamente utilizável, dado que o depósito era em dólar, a moeda usada nas transações internacionais no pós-guerra. Mesmo assim, até 1957, mais da metade da carteira de empréstimos do BIRD foi direcionada para países da Europa e o Japão. 
${ }^{3}$ Em julho de 1947, a revista Foreign Affairs publicou o artigo intitulado The sources of soviet conduct, escrito por Kennan, então funcionário do Departamento de Estado, sob o pseudônimo de "X". O texto sistematizava as linhas centrais da estratégia de "contenção" do comunismo. Sobre o ambiente que cercou a formulação do documento, ver Fontana (2010, p. 60-63).

${ }^{4}$ Realizada em Bandung, na Indonésia, a conferência foi convocada pelos governos da Índia, Birmânia, Ceilão, Indonésia e Paquistão. Participaram do evento representantes dos seguintes países: Afeganistão, Camboja, República Popular da China, Egito, Etiópia, Gana e Sudão (ainda colônias), Irã, Iraque, Japão, Jordânia, Laos, Líbano, Libéria, Líbia, Nepal, Filipinas, Arábia Saudita, Síria, Sião, Turquia, República Popular do Vietnã, Estado do Vietnã e Iêmen.

${ }^{5}$ Sobre as contradições e ambiguidades de Bandung e da articulação dos "não alinhados", ver Rist (2002, p. 98-106) e Ahmad (2002, p. 173-184).

${ }^{6}$ Diante do "perigo castrista", o Banco Mundial autorizou diversos empréstimos "emergenciais" no início dos anos sessenta a países da América Latina e do Caribe. De acordo com um membro graduado do Banco, era conveniente, naquele momento, dar mostras de "simpatia" aos governos da região (KAPUR et al., 1997, p. 163-164).

${ }^{7}$ Tais renegociações foram coordenadas, conforme cada caso, por arranjos institucionais constituídos pelo Clube de Paris, Clube de Haia, OCDE, FMI e consórcios internacionais de doadores (sob a liderança ou não do Banco Mundial) (MASON; ASHER, 1973, p. 224).

${ }^{8}$ Uma das coordenadas intelectuais que guiavam o Banco desde os anos 1950 era a ideia de que a distribuição de renda se concentrava nos estágios iniciais do ciclo econômico e se desconcentrava nos estágios finais, de tal maneira que, após uma fase ascendente de crescimento, operar-se-ia o "efeito derrame" (trickle-down), i.e., o gotejamento gradual de renda para os estratos mais baixos da estrutura social (KAPUR et al., 1997, p. 116-117). Quanto tempo demoraria e qual o alcance do derrame acabaram se tornando questões secundárias naquele período frente à própria crença no derrame.

\section{Referências}

AHMAD, Aijaz. Linhagens do presente. São Paulo: Boitempo, 2002.

AYRES, Robert. Banking on the Poor: the World Bank and World Poverty. London: MIT Press, 1983.

BANCO MUNDIAL. Annual Report 1964-1965. Washington, D.C.: World Bank, 1965. 


\section{João Márcio Mendes Pereira}

BANDEIRA, Luiz Alberto Moniz. Formação do império americano: da guerra contra a Espanha à guerra no Iraque. Rio de Janeiro: Civilização Brasileira, 2. ed, 2006. BLOCK, Fred. Los origenes del desorden económico internacional. México, D.F.: FCE, 1989.

BURBACH, Roger; FLYNN, Barbara. Agroindústria nas Américas. Rio de Janeiro: Zahar, 1982.

CAUFIELD, Catherine. Masters of Illusion: the World Bank and the Poverty of Nations. New York: Henry Holt, 1996.

DEZALAY, Yves; GARTH, Bryant. La internacionalización de las luchas por el poder. México, D.F.: Instituto de Investigaciones Jurídicas/Universidad Nacional Autónoma de México, 2005.

EICHENGREEN, Barry. A globalização do capital: uma história do sistema monetário internacional. São Paulo: Editora 34, 2000.

EVANS, Peter. A tríplice aliança: as multinacionais, as estatais e o capital nacional no desenvolvimento dependente brasileiro. Rio de Janeiro: Zahar, 1980.

FONTANA, Josep. Por el bien del imperio: una historia del mundo desde 1945. Barcelona: Pasado \& Presente, 2011.

GARCÉS, Joan. Soberanos e intervenidos: estrategias globales, americanos y españoles. Madrid: Siglo XXI, 3. ed., 2008.

GARDNER, Richard. La diplomacia del dólar y la esterlina. Barcelona: Galaxia Gutenberg/Círculo de Lectores, 1994.

GAVIN, Michael; RODRIK, Dani. The World Bank in historical perspective. American Economic Review, v. 85, n. 2, May, p. 329-34, 1995.

GEORGE, Susan. O mercado da fome. Rio de Janeiro: Paz e Terra, 1978.

GOLDMAN, Michael. Imperial Nature: the World Bank and Struggles for Social Justice in the Age of Globalization. New Haven/London: Yale University Press, 2005.

GWIN, Catherine. U.S. relations with the World Bank, 1945-1992. In: KAPUR, Devesh et al (Eds.) The World Bank: its First Half Century. Washington, D.C.: Brookings Institution Press, vol. 2, p. 195-274, 1997.

HELLEINER, Eric. States and the reemergence of global finance: from Bretton Woods to the 1990s. Ithaca/London: Cornell University Press, 1994.

HOBSBAWM, Eric. Era dos extremos. O breve século XX. São Paulo: Companhia das Letras, 1995. 
KAPUR, Devesh et al. The World Bank: its First Half Century. Washington, D.C.: Brookings Institution Press, vol. 1, 1997.

KIRK, Jason. India and the World Bank. London/New York: Anthem, 2010.

KOFAS, Jon. Independence from America: Global Integration and Inequality. Burlington: Ashgate, 2005.

. The sword of Damocles: U.S. financial hegemony in Colombia and Chile, 1950-1970. Westport: Praeger, 2002.

. Stabilization and class conflict: the State Department, the IMF, and the IBRD in Chile, 1952-1958. The International History Review, v. 21, n. 2, June, p. 352-85, 1999.

. The politics of austerity: the IMF and U.S. foreign policy in Bolivia, 1956-1964. The Journal of Developing Areas, v. 29, n. 2, January, p. 213-35, 1995.

KOLKO, Gabriel. The Politics of War: the World and United States Foreign Policy, 1943-45. New York: Pantheon, 1990.

KRIGE, John. American Hegemony and the Postwar Reconstruction of Science in Europe. Cambridge/London: MIT Press, 2006.

LANCASTER, Carol. Foreign Aid: Diplomacy, Development, Domestic Politics. Chicago/London: The University of Chicago Press, 2007.

LAPPÉ, Frances M; COLLINS, Joseph. Comer és primero: más allá del mito de la escasez. México: Siglo XXI, 1982.

LATHAM, Michael. Modernization as Ideology: American Social Science and "Nation Building" in the Kennedy Era. Chapel Hill/London: The University of Carolina Press, 2000.

MAGDOFF, Harry. A era do imperialismo: a economia da política externa dos Estados Unidos. São Paulo: Hucitec, 1978.

MASON, Edward; ASHER, Robert. The World Bank since Bretton Woods. Washington, D.C.: The Brookings Institution, 1973.

McNAMARA, Robert. A essência da segurança. São Paulo: IBRASA, 1968.

OLIVER, Robert. George Woods and the World Bank. Boulder/London: Lynne Rienner, 1995.

PAULY, Louis. Who elected the bankers? Surveillance and control in the world economy. Ithaca/London: Cornell University Press, 1997.

PAYER, Cheryl. Lent and Lost: Foreign Credit and Third World Development. London/New Jersey: Zed Books, 1991. 


\section{João Márcio Mendes Pereira}

1982.

The World Bank: a Critical Analysis. New York: Monthly Review Press, The Debt Trap: the International Monetary Fund and the Third World. New York: Monthly Review Press, 1974.

PEREIRA, João Márcio Mendes. O Banco Mundial como ator político, intelectual e financeiro (1944-2008). Rio de Janeiro: Civilização Brasileira, 2010.

PERKINS, John H. Geopolitics and the Green Revolution: Wheat, Genes, and the Cold War. New York: Oxford University Press, 1997.

RICH, Bruce. Mortgaging the Earth: the World Bank, Environmental Impoverishment, and the Crisis of Development. Boston: Beacon Press, 1994.

RIST, Gibert. El desarrollo: historia de una creencia occidental. Madrid: Catarata, 2002.

ROBIN, Ron. The Making of the Cold War Enemy: Culture and Politics in the Military-Intellectual Complex. Princeton/Oxford: Princeton University Press, 2001.

ROSTOW, Walter W. A estratégia americana. Rio de Janeiro: Zahar, 1965.

SCHULTZ, Theodor. A transformação da agricultura tradicional. Rio de Janeiro: Zahar, 1965.

SHIVA, Vandana. The Violence of Green Revolution. London/New Jersey: Zed Books, 1991.

SOGGE, David. Dary tomar: ¿qué sucede con la ayuda internacional? Barcelona: Icaria Editorial, 2002.

TABB, William. Economic Governance in the Age of Globalization. N ew York: Columbia University Press, 2004.

TOUSSAINT, Eric. Banco Mundial: el golpe de Estado permanente. Madrid: El Viejo Topo, 2006.

VAN DORMAEL, Armand. Bretton Woods: Birth of a Monetary System. London: MacMillan, 1978.

WINDERS, Bill. The Politics of Food Supply: U.S. Agricultural Policy in the World Economy. New Haven/London: Yale University Press, 2009.

WOODS, Ngaire. The Globalizers: the IMF, the World Bank and their Borrowers. Ithaca/London: Cornell University Press, 2006.

Recebido em: 15/06/2013

Aprovado em: 23/10/2013 